\title{
Mapping Residents' Perceptions on the Challenges Confronting Participatory Budgeting Processes in Urban Municipalities in Zimbabwe: A Case Study of Chitungwiza Municipality
}

\author{
Jerry Chigumbu
}

\begin{abstract}
The studies on good governance in local authorities' have taken a center stage in urban participatory and inclusive development debates. This is the case with particularly Participatory Budgeting (PB) in Chitungwiza Municipality he essence of $\mathrm{PB}$ is to afford citizens a direct role in governance activities in their areas. Local Government contexts offer the best conditions for participatory Budgeting in pursuit of good governance. A sample population of 70 respondents was used in this study. A mixed methods design was employed. Interviews, Focus Discussion Groups and a 5-point Likert scale survey questionnaire were used to gather the data. The central research question was on the challenges confronting participatory budgeting processes in Chitungwiza Municipality. Qualitative data was used to establish themes from which challenges were derived. Quantitative design was used to measure the extent of the identified challenges using a 5-point Likert scale. Data analysis was done using thematic analysis and Microsoft Excel was used to generate a table of results. The study found out 8 key challenges inhibiting good Participatory Budgeting processes in Chitungwiza Municipality. The study recommended for further research into how the identified challenges constrain the participatory budgeting processes in order to derive sustainable, effective and targeted solutions.
\end{abstract}

Keywords: Participatory budgeting, Good governance, Local authorities

DOI: $10.7176 / \mathrm{EJBM} / 12-18-11$

Publication date:June 30th 2020

1. Background and introduction

The period preceding the direct involvement of citizens and civil society in the political sphere, for example, local authorities' budgeting, was marked by a long-term hegemony of elitism and scepticism about the broad participation of ordinary people. Over the years, participatory budgeting gained salience as a 'good governance' enhancing process in terms of budgeting in local authorities. The desire to promote good governance concerning participation, transparency, accountability, quality service delivery and responsiveness to residents or ratepayers' needs gave impetus to participatory budgeting (Zinyama, 2014). Zinyama (2014) notes that the need for a closer relationship between Municipalities and their stakeholders was emphasized by world leaders at the 1992 Rio Earth Summit, which endorsed the Local Agenda 21 and highlighted the need for people from all sections of the community and all parts of the world, to take joint responsibility for development decisions. According to Shah, 2007), the enhanced transparency and accountability created by participatory budgeting help reduce inefficiencies and corruption. According to Ganuza, and Baiocchi (2012), It has managed to attracted international attention, becoming a best practice that was taken up by the international networks. However, to date, a culture of effective participatory budgeting has yet to take firm root in many local authorities. This seems to be the case in Chitungwiza Municipality. Consequently, good governance seems to have been undermined in the Municipality. It is against this background that this paper examines the challenges confronting participatory budgeting processes in Chitungwiza Municipalities in Zimbabwe. Results of this study will be used to understand and ameliorate similar challenges facing other urban municipalities.

The initiative of participatory budgeting emanated from Brazil's City of Porto Alegre in 1989 in an attempt to resuscitate a bankrupt municipality and a disorganized bureaucracy with the view to provide citizens with a direct role in the activities of government and improve the governance system (Wampler, 2000). Participatory budgeting was soon adopted across the globe as a best practice (Cabanes and Lipietz, 2017; De Oliveira, 2017). Cabannes (2014) observes that it brings social justice and participatory democracy thereby representing a direct democracy approach to budgeting. By definition, PB is a process whereby communities work together with elected representatives and officials to develop policies and budgets to meet the needs of their communities (Economic Justice Update, 2001). According to UN-HABITAT (2004), it is a process through, which the population makes decisions on, or contributes to the decisions made on or part of the available public resources. To Allegretti (20060) in UN-HABITAT (2008. p3) "it refers to turning over budgetary decisions to the citizens for whom the budget has a direct bearing, creating public arenas in which citizens can discuss and set the city's priorities or choose some new investments affecting a (more or less) huge percentage of the municipal budget". Local Authorities (LAs) are adopting the PB approach to rebuild their relationships with service users and eliminate citizen apathy which negatively affects service delivery (Poverty Reduction Forum Trust, 2017). In Zimbabwe, very few local authorities, including Harare City Council and Chitungwiza Municipality have embraced this budgeting approach 
(Poverty Reduction Forum Trust, 2017). The aim was to foster citizen involvement in the budgeting process of local authorities

\subsection{The legal framework}

Worryingly, in Zimbabwe, there seems to be a piecemeal implementation of PB in local authorities. In part, this is because there is no specific law enforcing community participation in the budgeting process. The current constitutional provisions for citizen participation are obscure and vague, with section 264 (2b) of the 2013 Constitution of Zimbabwe, Amendment (No.20) recognising the need to give powers of local governance to the people and enhance their participation in the exercise of the powers of the state and in making decisions affecting them. Section 264 (d) also recognises the right of communities to manage their affairs and to further their development. However, because the provisions are objectives of devolution, they are conditional since Section 264(1) states that "Whenever appropriate", governmental powers and responsibilities must be devolved to provincial, metropolitan councils, and LAs which are "competent" to carry out those responsibilities efficiently and effectively (Constitution of Zimbabwe Amendment (No.20) Act 2013). The Local Government Amendment Laws Act of 2016 Gazetted on 26th August 2016 is silent on issues of devolution which remains a challenge to the activation of constitutional provisions on devolution and, ultimately, the full adoption of PB in Zimbabwe (The Poverty Reduction Forum Trust, 2017). The Urban Councils Act, Chapter 29: 15 of 1995, makes peripheral provision for PB in LAs in Zimbabwe. Sec 288 (1) of the Act reads:

Before the expiry of any financial year the finance committee shall draw up and present for the approval of the council estimates in such detail as the council may require of the income and expenditure on revenue and capital accounts of the council for the next succeeding financial year. When the estimates presented in terms of subsection (1) have been approved by the council and signed by the mayor or chairman of the council, as the case may be, the council shall ensure that-(a) copies of the estimates are forthwith made available for inspection by the public

The Act stipulates that all local government budget proposals are to be published in three issues of the newspaper so as to give the public a chance to scrutinise the budget (Chikerema 2013). Chikerema further notes that PB as a legislative creature was introduced as:

...part of the overall strategic effort to promote local democracy in local authorities and its main objectives are: to promote civic interest and participation in local governance, to involve the community in generating self-sustaining livelihoods options as well as to promote accountability and transparency in local public finance and budgeting (2013:3).

In light of the legal framework articulated in this paper, the study focuses on the implementation of participatory budgeting a component of good governance in Chitungwiza Municipality. The study proceeds from the conjecture that there are asymmetries in the way participatory budgeting is being conducted in Chitungwiza Municipality, undermining good governance. The proposition is that the residents of Chitungwiza have not been sufficiently involved in budget decision making.

As indicated on its website, Chitungwiza Municipality is an urban local authority established in terms of the Urban Councils Act in 1978. Chitungwiza was initially created as a dormitory town for Harare and was granted Town Council status in 1981 and Municipal status in 1995. It is located approximately 30 kilometers South of Harare. Chitugwiza Municipality is the third largest urban settlement in Zimbabwe, after Harare and Bulawayo. The Municipality is an amalgamation of three residential areas: Sake, St Mary's and Zengeza, together with the additional component of the insignificant industrial area. According to the 2012 census, it had a population of 356 , 840 .

\subsubsection{Methodology}

A mixed methods research design was used in this study. A sample of 70 respondents was used in this study. Thirty-three interviews were carried out and Five focus group discussion was conducted to gather qualitative data. Thematic analysis was used to come up with broad challenges. At the confirmatory stage, a five-point Likert scale was used to confirm and measure residents' perceptions on the extent to which these challenges have affected the participatory budgeting process. A sample of 70 respondents was considered in the retrospective analysis of the challenges confronting participatory budgeting processes in Chitungwiza Municipality between 2010 and 2019.

\subsubsection{Results and Discussion}

Thirty-three interviews and five focus group discussions were conducted in this study in the initial stage of this study. Qualitative data were solicited and examined through thematic analysis. Eight thematic areas were observed from the qualitative data analysis. The eight challenges derived from the themes are; access to budget, Central Government interference, lack of commitment, poor communication on participatory budgeting related issues, the politicisation of the participatory budgeting, polarisation, resident's apathy and public distrust. These were perceived as major challenges affecting the participatory budgeting process in Chitungwiza. The further analysis 
measured the respondent's perceptions of the extent to which these challenges occurred. A five point Likert scale questionnaire was used to measure the extent to which the problems are impacting the participatory process in Chitungwiza. Table 1.1 shows the results of the survey based on the respondent's perceptions.

Table 1.1 Residents perceptions on the measurement of the identified challenges on the PB process.

\begin{tabular}{|l|l|l|l|l|l|l|l|l|l|l|l|}
\hline PB Challenges & $\begin{array}{l}1=\text { Very } \\
\text { Low }\end{array}$ & $\%$ & $2=$ Low & $\%$ & $3=$ Fair & $\%$ & $4=$ High & $\%$ & $\begin{array}{l}5=\text { Very } \\
\text { High }\end{array}$ & $\%$ & N= \\
\hline Access to budget & 62 & $89 \%$ & 5 & $7 \%$ & 1 & $1 \%$ & 2 & $3 \%$ & 0 & $0 \%$ & 70 \\
\hline CG interference & 2 & $3 \%$ & 1 & $1 \%$ & 1 & $1 \%$ & 66 & $94 \%$ & 0 & $0 \%$ & 70 \\
\hline Commitment & 58 & $83 \%$ & 9 & $13 \%$ & 2 & $3 \%$ & 1 & $1 \%$ & 0 & $0 \%$ & 70 \\
\hline Communication & 17 & $24 \%$ & 50 & $71 \%$ & 3 & $4 \%$ & 0 & $0 \%$ & 0 & $0 \%$ & 70 \\
\hline $\begin{array}{l}\text { Political } \\
\text { Polarisation }\end{array}$ & 0 & $0 \%$ & 2 & $3 \%$ & 2 & $3 \%$ & 8 & $11 \%$ & 58 & $83 \%$ & 70 \\
\hline Politicisation & 1 & $1 \%$ & 1 & $1 \%$ & 4 & $6 \%$ & 9 & $13 \%$ & 55 & $79 \%$ & 70 \\
\hline Residents apathy & 0 & $0 \%$ & 0 & $0 \%$ & 5 & $7 \%$ & 54 & $77 \%$ & 11 & $16 \%$ & 70 \\
\hline $\begin{array}{l}\text { Trust and } \\
\text { credibility and }\end{array}$ & 41 & $59 \%$ & 13 & $19 \%$ & 10 & $14 \%$ & 6 & $9 \%$ & 0 & $0 \%$ & 70 \\
\hline
\end{tabular}

Source: Field Survey Data

\subsubsection{Access to a physical budget}

The limited access to the physical budget was indicated as one of the challenges facing the proper implementation of the PB process. Miori and Russo (2011) emphasize the importance of access to budgetary information by residents. In the survey, $89 \%(\mathrm{~N}=70)$ of the respondents rated access to the budget as very low thereby constraining their ability to analyze the budget to make a meaningful contribution towards its amelioration. The respondents also highlighted the evidence of the Municipality's unwillingness to have residents access the Budget. Reference was made to repeated incidents by $60 \%$ of the respondents when the council officials explicitly stated that anyone was free to visit the council anytime during work hours and get a copy of the budget. They, however, the participants claimed that upon getting to the council to get a copy of the budget, they realised that Municipal police had already been directed to bar those who had the intention of getting the budget from entering the council premises. The failure by residents to obtain a copy of the budgets negatively affected the nature, scope, and extent of PB in Chitungwiza Municipality. What it essentially meant was that residents could not be meaningfully involved continuously in the budgeting process.

\subsubsection{Central Government Interference}

Interference of the Central Government in Local Authorities matters was identified as a challenge by the respondents. Its influence was tested using a 5-point Likert scale. The results of the survey indicated that $94 \%$ $(\mathrm{N}=70)$ of the respondents rated the challenge of central government interference in council matters high, $3 \%$ very low and $1 \%$ low. Thus, the results suggest central government interference as an inhibitor to a successful implementation of the PB process in Chitungwiza during the period in question. In this regard respondents during the FGD cited that:

"that the Minister of Local Government seemed to interfere too much in the Municipalities business. The participants said that even when the Municipality is informed of what the residents would want, there was need to get the green light from the Minister first. Without the Minister's approval, the proposals of the residents would not see the light of the day, but instead suffer still birth."

Similarly, these sentiments are supported by the feelings of the residents as expressed in the PPC Report to the Ministry in 2010. In a PPC report of the Ministry of Local Government, Rural and Urban development in 2010, residents noted that the councillors were mere rubber stampers who did not have a say in most of the council issues and the way the council expended its resources.

Further to that, one of the interviewed councillors cited a 2012 case in which the then Minister of Local Government, instructed that residents pay a land sale fee of $\$ 8.00$ per $200 \mathrm{~m} 2$ to have ownership of houses. Affected were residents who had been promised that after 25 years they will be paying lesser rates. This discouraged resident to pay rates. Thus, it can be concluded that results of the study show that interference by the Minister inhibited good governance of the PB process and virtue of the involvement of the powerful Minister, residents' views could not be taken on board.

1.1.5 Lack of Commitment to Implement PB on the Part of Council

The study identified lack of commitment of the council to implementation of the PB process. In the light of the lack of commitment identified through the interviews, the respondents were asked to rate the level of council commitment to the PB implementation and $83 \%(\mathrm{~N}=70)$ rated the commitment as Very low, 13\% rated it low and 
$0 \%$ rated it very high. Overall the study revealed that $93 \%(\mathrm{~N}=70)$ of the respondents felt that the council conducted the PB as a mere formality without commitment. The respondents said that the council presented an already made budget to residents to ratify instead of involving the residents into the buildup processes to the budget end product. The consultations were therefore described as "merely cosmetic". It was strongly felt by the respondents that once elected, the councillors tended to form a clique that is impervious and essentially inwardlooking and self-serving.

\subsubsection{Poor Communication and limited time}

Poor communication emerged as another challenge affecting the PB process in Chitungwiza. Cunha, et al. (2011) points out the importance of effective communication in the participatory budgeting process. The study indicated that $71 \%(\mathrm{~N}=70)$ attested to low communication and $24 \%(\mathrm{~N}=70)$ to very low communication. Overall $95 \%(\mathrm{~N}=70)$ confirmed that the communication between the residents and the council is low and very poor thereby strangulating the proper implementation of the PB process in Chitungwiza. The Councillors interviewed $(100 \%)$ indicated that residents complain about the communication channel used by the Council to inform them of PB meetings and the limited time they are given to prepare for the budget meetings. Adequate time for residents to prepare is one of the success factors of PB (Adesopo, 2011). Most the respondent's complained that the placing of the budget in the newspaper as was done by the Municipality was really not an effective way of reaching out to a majority of citizens as only a few indeed buy and read newspapers. They thus viewed this as s deliberate and convenient ploy to disenfranchise most residents from effective participation in the PB process.

\subsubsection{Political Polarisation at Council}

Political polarization at the council was found to be an inhibitor to effective implementation of the PB process. According to Eames (2017), political polarization devised people and decisions scattered across party lines making it difficult to converge ideas based on usefulness. The respondents rated political polarisation Very High at $83 \%$ and high at $11 \%(\mathrm{~N}=70)$. Results show that politics affected the effective running affairs at Chitungwiza Municipality. The respondents noted that Councilors who were supposed to represent people acted in a partisan way to outwit perceived opponents from another party. In such political battles, they ended up passing decisions favourable to the political group they belong to instead of making decisions that benefit the Municipality and residents. In this regard, the paternalistic and political meddling in PB reduced Chitungwiza Municipality to more or fewer extensions of party politics. The political interference had destructive ramifications on the PB process as it becomes difficult for Chitungwiza Municipality to hold productive consultative meetings with residents. This also affected Chitungwiza Municipality employees who were suspected to be politically aligned. More importantly, this affected payment of rates by residents resulting in low revenue collection.

\subsubsection{Politicisation of Participatory Budgeting Meetings}

The results of the study also indicate that Politicisation of Participatory Budgeting Meetings compromised the integrity of the PB process in Chitungwiza Municipality. The results show that $79 \%(\mathrm{~N}=70)$ indicated Very High Politicisation and 13\% (N=70) attested to high Politicisation of PB meetings. Put together 92\% $(\mathrm{N}=70)$ attested to high Politicisation of budgetary meetings. The respondents termed most stakeholders as "hired thugs". One respondent pointed out that people were sponsored to disrupt the meetings and cited the 2013 Zengeza 1-5 disrupted meetings. Political slogans and intimidation were reported to be characteristic of the actions by the disrupters which made the environment not conducive for the meetings. The respondents also highlighted that most participants were denied a chance to voice their concerns. Name-calling and booing characterised the processes. More so, a CHITREST key informant interviewed reported that the council officials in charge of the process would not pick a participant in the meeting whom they felt or knew would likely give a critical view. They would selectively pick on participants whom they knew would not raise any critical issues. This politicization created an environment that was not conducive to a credible, constructive, free and fair process. This kind of behaviour discourages future participation as well as the legitimacy of the participatory budgeting. Overall, high politicization was observed by the respondents during participatory budgeting in Chitungwiza.

\subsubsection{Trust and credibility}

Following the Politicisation of the meetings, the polarisation at the council, the poor communication and the central government interference, the respondents noted that the trust and credibility of the PB outcome were endangered. From the survey,59\% $(\mathrm{N}=70)$ of the respondents rated the trust and credibility Very Low and $19 \%(N=70)$ rated it Low and 14\% fair. However overall 78\% ( $=70)$ rated the trust and credibility of the $\mathrm{PB}$ outcome in Chitungwiza at least low. It also emerged from the research that the bad governance reputation of council negatively affected PB in Chitungwiza Municipality. 


\subsubsection{Residence Apathy}

Linked to the low trust, credibility and bad reputations are the residents' discontent and apathy towards the PB process. The search results indicate that apathy was rated high by $77 \%(\mathrm{~N}=70)$ and very high by $16 \%$ of the respondents. Similar results were found by Maduna, et al. (2015) on the study of participatory budgeting processes of Harare City council between 1995 to 2013. The participants said that as a result of the politicisation of PB meetings, and the fact that the contributions that citizens make do not reflect in the final budget, citizens lost interest in the PB process. According to one FGD participant, "nobody would bother to sacrifice their time to attend PB meetings that would not result in anything from which they would benefit". One of the interviewed councillors said that reluctance to attend PB meetings, particularly on the part of the elderly, was a result of fear that the meetings may become riotous as before. It can be noted that the extent of PB in Chitungwiza Municipality was also limited by the apathy amongst residents who have not seen much happening as a result of the pseudoconsultative nature of the PB process.

\subsection{Conclusions and Recommendations}

While acknowledging the importance of identifying the threats to participatory budgeting and its associated solutions, the scope of this study was limited to identification of challenges confronting participatory Budgeting processes in Chitungwiza Municipality based in the resident's perceptions to prepare a solid foundation for further research on the solutions to the challenges. The study found eight major challenges affecting the participatory budgeting process in Chitungwiza. These challenges are limited to access to budget, increased central government interference, lack of commitment, poor communication on related issues, Politicisation, polarization resident's apathy and public distrust. These identified eight challenges testify to the conclusion that participatory budgeting was not being carried effectively in Chitungwiza Municipality.

In light of the study results, the following recommendations were derived. There is a need for further research on the identified eight challenges to determine the scope and the context within which they manifest in order to formula well-informed solutions to the challenges. More information on how these identified 8 challenges reinforce each other is needed to separate core problems from symptoms of the problems when creating solutions to the identified participatory budgeting challenges found in Chitungwiza.

Notwithstanding the need for further research on the solutions, the following recommendations were a direct outcome of the study. The identified challenges fall under the broad domain of good governance and as such focus of mitigation must lie within realigning the Participatory processes with principles of good governance. Thus, the public and council need to be empowered on principles of good governance so that they can become watchdogs on good governance observance during the process.

Chitungwiza Municipality should involve residents at all stages in PB; from formulation through to evaluation. This will allow residents to identify, discuss and prioritise public spending projects and gives them the power to make real decisions about how revenue is spent at the municipality and subsequently impacts on the quality of service delivery. Additionally, PB has an integrative function as it contributes to residents feeling of being part of the municipality. As a consequence, they may also feel more responsible personally for rates payment.

Chitungwiza Municipality should mobilise residents to attend PB meetings. Furthermore, the Municipality should also strive to ensure that residents participate in budget consultative meetings through public awareness, distribution of posters and flyers when the days of crucial meetings draw close. At the same time, the responsible authority must continuously remind Councillors of their mandate at the municipality, which is promote service provision.

Chitungwiza Municipality could improve on PB communication by attaching leaflets relating to PB to the invoices that are sent to the residents monthly. The Municipality should also hold PB-related roadshows, and circulate copies of the budget or proposed projects by knock and drop. Copies of the budget should be accessible from Council and be availed on Chitungwiza Municipality's website. Chitungwiza Municipality should create methods to increase accessibility to information necessary for ensuring meaningful participation with the principles of transparency, accountability, consistency and enabling the systematization of information to provide input to the public decision-making process.

Chitungwiza Municipality must strive to ensure that residents participate in the PB process and their opinions are implemented at the end. However, the major problem is the implementation of discussed issues. Often than not, Chitungwiza residents find their inputs missing in the final budget document or implantation stage.

RAs and Chitungwiza Municipality should jointly increase the quality of feedback provided to residents, as feedback significantly determines the prevalence of participation. PB requires the application of effective and efficient systems that are accessible to all residents and focused on the responsibilities of residents to participate in decisions that influence their lives. 
Municipality. The point of departure was the conjecture that the lack of PB has undermined good governance in Chitungwiza Municipality. Using key informant interviews with Councillors and individuals from RAs, as well as FGDs with residents in Chitungwiza Municipality, the study examined the practice of PB between 2010 and 2019. It established the nature, scope, and extent of PB, and the challenges that were encountered. The study recommends and proposes a workable approach towards the implementation of PB to enhance effective service delivery with some contributions towards a framework of good governance

\subsubsection{References}

Adesopo, A.A. (2011). "Inventing Participatory Planning and Budgeting for Participatory Local Governance in Nigeria". International Journal of Business and Social Science, Volume No :http://www.ijbssnet.com/journals/Vol.2__No._7\%3B_Special_Issue_April_2011/13.pdf (accessed: 10 March 2017

Cabannes, Y. and Lipietsz ,B. (2017). Environment \& Urbanization Copyright (C) 2017 International Institute for Environment and Development (IIED). Vol 30(1): 67-84. DOI:

10.1177/0956247817746279 www.sagepublications.com

Cabannes, Y. (2014). Contribution of Participatory Budgeting to provision and management of Basic services: municipal practices and evidence from the field. IIED Working Paper. IIED, London. http://pubs.iied.org/10713IIED

De Oliveira P.O. (2017). International Policy Diffusion and participatory Budgeting. Ambassadors Of Participation, International institutional networks, Palgrave.

Eleanora S. M., Cunha, E.S. M. Allegretti, G and Matias, M. (2011). Participatory Budgeting and the Use of Information and Communication Technologies: A Virtuous Cycle? », RCCS Annual Review [Online], $3 \mid 2011$, Online since 01 October 2011, connection on 06 May 2020.URL :http://journals.openedition.org/rccsar/316 ;DOI : https://doi.org/10.4000/rccsar.316

Eames, A. (2013). "The Relationship Between Comprehensive Budgeting and Party Polarization in the U.S. Congress" (2013). CHITUNGWIZA MUNICIPALITY C Senior Theses. Paper, 570.http://scholarship.claremont.edu/Chitungwiza Municipality theses/570

Ganuza, E. and Baiocchi, G. (2012). "The Power of Ambiguity: How Participatory Budgeting Travels the Globe". Journal of Public Deliberation, 8 (2) Available at: http://budgetparticipatif.info/wpcontent/uploads/2016/10/How-Participatory-Budgeting-Travels-the-Globe.pdf (accessed: 29 March 2017).

Manduna, K., Zinyama, T., Nhema, AG. (2015). Local Government Participatory Budget System in Zimbabwe: The Case of Harare City Council, 1995-2013 Vol.5, No.11, 2015, Public Policy and Administration Research www.iiste.org

Miori, V and Russo, D. (2011). "Integrating Online and Traditional Involvement in Participatory Budgeting" Electronic Journal of e-Government Volume 9 Issue 1 2011, (pp41 - 57), available online at www.ejeg.com

Shah, A. (2007). Participatory Budgeting. Public Sector Governance and Accountability. Washington, DC: World Bank. (C World Bank. https://openknowledge.worldbank.org/handle/10986/6640 License: CC BY 3.0 IGO."

United Nations Human Settlements Programme (UN-HABITAT) (2008), Participatory Budgeting in Africa: A Training Companion with cases from eastern and southern Africa Volume I: Concepts and Principles, UN/Publishing Section Services, Nairobi, Kenya

UN HABITAT, (2004). 72 Frequently Asked Questions about Participatory Budgeting. Ur-ban Governance Toolkit Series. Participatory Budgeting in Africa Volume I: Concepts and Principles. At http//www.participatorybudegting.org.uk/Linkpage.htm

Wampler, B. (2000). A Guide to Participatory Budgeting. Available at: https://www.commdev.org_GPB.pdf (accessed: 22 March 2017).

Zinyama, T. (2014). "Participatory Budgeting in Zimbabwe: Experiences and Reflections From Harare City Council". British Journal of Physical and Human Geography, 1 (1), 1-44 [Online], Available at: www.gbjournals.org.pdf (accessed: 16 March 2017).

Originality

I swear that this work is my original work is my original work and is not part of any work unpublished or published elsewhere. 